\title{
Ensuing Economic Gains due to Different Dates of Sowing on Finger millet Varieties (Eleusine coracana L.)
}

\author{
R. D. Nigade*, S. V. Bagade and R. L. Bhilare
}

Mahatma Phule Krishi Vidyapeeth, College of Agriculture, Pune, Maharashtra 05, India

*Corresponding author

\section{A B S T R A C T}

\begin{tabular}{l} 
K e y w o r d s \\
$\begin{array}{l}\text { Economics, Grain } \\
\text { yield, Test weight, } \\
\text { No of fingers }\end{array}$ \\
Article Info \\
$\begin{array}{l}\text { Accepted: } \\
18 \text { April } 2020 \\
\text { Available Online: } \\
\text { 10 May } 2020\end{array}$ \\
\hline
\end{tabular}

A field experiment to study the effect of different sowing dates on growth and yield of finger millet cultivars under rainfed conditions was conducted during three consecutive kharif seasons of 2016, 2017 and 2018 at the experimental farm of Zonal Agricultural Research Station, Sub-montane Zone, Kolhapur (Maharashtra) India. The experiment was conducted with four dates of sowing as main plot $\left(2^{\text {nd }}\right.$ week of June, $4^{\text {th }}$ week of June, $2^{\text {nd }}$ week of July and $4^{\text {th }}$ week of July) and four finger millet varieties (Phule Nachani, GPU 28, GPU 67 and Dapoli 1) as sub-plot in split plot design with three replications. Pooled results of the three years showed that the significantly highest plant height $(88.7 \mathrm{~cm})$, number of tillers $(2.6)$, length $(7.3 \mathrm{~cm})$ and number of fingers $(6.5)$, was recorded with second sowing date i.e. on $4^{\text {th }}$ week of July. However, significantly highest grain and straw yield (22.51 and $29.88 \mathrm{q} \mathrm{ha}^{-1}$ ) as well as monetary returns was observed with sowing of finger millet variety Phule Nachani in $4^{\text {th }}$ week of June i.e. $26^{\text {th }} \mathrm{MW}$ on shallow and light soils in IX rainfall situation of sub-montane zone of Maharashtra.

\section{Introduction}

In recent years climate change and its variability are emerging as major challenges to Indian Agriculture. Although, climate change impacts are being witnessed world over, the countries in which larger population is dependent on agriculture, such as India, are more vulnerable. Recent research indicated that monsoon rainfall in India became more erratic with intense rainfall events and reduced number of rainy days during the latter half of the $20^{\text {th }}$ century thus increasing the risk of drought and flood damage to crops like rice (Auffhammer et al., 2012).

Rainfed crops are more vulnerable to climate change because of the limited options for coping with variability of rainfall and temperature. This will result in shift in sowing time and shorter growing season, which may necessitate effective adjustment in sowing and harvesting dates. One of the striking features of finger millet is its resilience and ability to 
adjust to diverse agro-ecological conditions which is reflected in having highest productivity among millets (Seetharam, 2006). It is grown under diverse situations of soil and all weather conditions more so varying rainfall situations. Finger millet is considered as one of the most drought resistant crops among the field crops with high production potential. Among several agronomic practices, time of planting is an important non-monetary input for realizing higher productivity in any crop. Optimum sowing time and selection of improved cultivars play a remarkable role in exploiting the yield potential of the crop under particular agro-climatic conditions. Hence, it was thought worthwhile to study the effect of sowing dates on finger millet varieties in relation to climate change.

\section{Materials and Methods}

The investigation was conducted during kharif seasons for three years 2016 to 2018 at the Zonal Agricultural Research Station, Shenda Park, Kolhapur (Maharashtra) at latitude of $16^{\circ} 43^{\prime} \mathrm{N}$, longitude $74^{\circ} 14^{\prime} \mathrm{E}$ and altitude $574 \mathrm{~m}$ above mean sea level. It comes under Sub-montane Zone of Maharashtra. The experimental site was silty loam with $\mathrm{pH}$ 7.20, E.C- $0.15 \mathrm{dSm}^{-1}$, organic carbon 0.48 per cent. The available nutrient status was low in $\mathrm{N}$ (198. $\left.\mathrm{kg} \mathrm{ha}^{-1}\right)$, medium P $\left(10.3 \mathrm{~kg} \mathrm{ha}^{-1}\right)$ and low in $\mathrm{K}\left(145 \mathrm{~kg} \mathrm{ha}^{-1}\right)$. The total annual rainfall received during 2016, 2017 and 2018 was $1067.6 \mathrm{~mm}$ in 59 rainy days, $972.2 \mathrm{~mm}$ in 70 rainy days and $1252.0 \mathrm{~mm}$ in 66 rainy days respectively. The dry spell during grand growth phase (33 to $35 \mathrm{MW}$ ) affects on yield of crop in all the years. The present experiment was laid out in split design four sowing dates $\left(24^{\text {th }} \mathrm{MW}, 26^{\text {th }} \mathrm{MW}, 28^{\text {th }} \mathrm{MW}\right.$ and $30^{\text {th }} \mathrm{MW}$ ) and varieties (Phule Nachani, GPU 28, GPU 67 and Dapoli 1 replicated three times. The gross plot size was $4.00 \times 3.0$

$\mathrm{m}^{2}$ and net plot of size $2.40 \mathrm{~m} \mathrm{X} 4.20 \mathrm{~m}$ was harvested for data collection. Seed rate of 3 $\mathrm{kg} \mathrm{ha}^{-1}$ was used for sowing at spacing $30 \mathrm{~cm}$ $\mathrm{x} 7.5 \mathrm{~cm}$ in all treatments. The crop was fertilized with a dose of $60 \mathrm{~kg} \mathrm{~N}$ and $30 \mathrm{~kg}$ $\mathrm{P}_{2} \mathrm{O}_{5}$ and $30 \mathrm{~kg} \mathrm{~K}_{2} \mathrm{O} \mathrm{ha}^{-1}$. Nitrogen supplied as urea, phosphorus as SSP potash as MOP. The tabulated data were statistically processed by standard method of analysis of variance for the split plot design and test of significance as given by Panse and Sukhatme (1985).

\section{Results and Discussion}

\section{Growth parameters}

Pooled ancillary observations on finger millet (Table 1) revealed that the finger millet sown during $2^{\text {nd }}$ week of July $\left(D_{3}\right)$ recorded significantly highest plant height $(88.7 \mathrm{~cm})$ over $4^{\text {th }}$ week of July. However, number of tillers (2.6), length of finger $(7.3 \mathrm{~cm})$ and no of fingers (6.5) were significantly highest sown during $4^{\text {th }}$ week of June $\left(\mathrm{D}_{2}\right)$. The significantly highest plant height $(94.3 \mathrm{~cm})$, number of tillers (2.7), and length of finger $(8.2 \mathrm{~cm})$ and number of fingers $(6.8)$ were recorded with the variety $\mathrm{V}_{1}-$ Phule Nachani.

The interaction effects between sowing dates and varieties were found to be nonsignificant. Similar findings were observed by Ashok E.G et al., (2004), Nagaraju and Mohan kumar (2006). Pandiselvi et al., 2010, and Revathi et al., (2018)

\section{Grain and straw yield}

Grain yield was significantly influenced by dates of sowing and varieties

\section{Effect of sowing date}

The data presented in Table 2, indicated that, the significantly highest grain and straw yield of finger millet $\left(18.20\right.$ and $23.64 \mathrm{q} \mathrm{ha}^{-1}$ respectively) was recorded with second 
sowing date i.e. on $4^{\text {th }}$ week of June over rest of the sowing dates. Among the varieties the significantly highest grain and straw yield of finger millet $\left(\begin{array}{lllll}18.30 & \& & 23.74 & \mathrm{q} & \mathrm{ha}^{-1}\end{array}\right)$ respectively was recorded with the variety Phule Nachani, which was significantly superior over all the varieties.

Interaction between dates of sowing and varieties revealed that the finger millet variety Phule Nachani sown during $4^{\text {th }}$ week of June recorded significantly highest grain and straw yield (22.51 and $29.88 \mathrm{q} \mathrm{ha}^{-1}$ respectively).

The higher grain yield recorded with $4^{\text {th }}$ week of June could be attributed to the cumulative effect of more tiller production and crop had an opportunity of longer growth period with sufficient light, temperature, relative humidity bright sunshine hours coupled with optimum day length which might have increased photosynthesis, in turn, dry matter production and yield. Under late sown conditions, lack of soil moisture due to cessation of rains also affects grain yield potential. Similar findings were observed by Parasuraman P (2001), Ashok E.G et al., (2004), Nagaraju and Mohan kumar (2006) and Pandiselvi et al., 2010 (Table 3).

\section{Economics}

The data pertaining to economics (Table 4) the highest gross returns, net returns and B:C ratio revealed that, the significantly highest gross and net monetary returns as well as B: C ratio (Rs. 45481, Rs. 15126, 1.50 respectively) was recorded with second sowing date i.e. on $4^{\text {th }}$ week of June over rest of the sowing dates. Among the varieties the significantly highest gross and net monetary returns as well as B: C ratio (Rs. 45853, Rs. 15749, 1.51 respectively) was recorded with the variety Phule Nachani, which was significantly superior over all the varieties.

Table.1 Pooled mean growth and yield attributing characters of finger millet as influenced by different treatments

\begin{tabular}{|c|c|c|c|c|}
\hline Treatments & $\begin{array}{c}\text { Plant height } \\
\text { (cm) }\end{array}$ & $\begin{array}{l}\text { No. of tillers } \\
\text { Plant }^{-1}\end{array}$ & $\begin{array}{l}\text { Length of } \\
\text { finger }(\mathrm{cm})\end{array}$ & $\begin{array}{l}\text { No. of fingers } \\
\text { ear }^{-1}\end{array}$ \\
\hline \multicolumn{5}{|l|}{ A. Sowing dates (4) } \\
\hline$D_{1}-2^{\text {nd }}$ Week of June & 85.0 & 2.4 & 6.9 & 5.8 \\
\hline$D_{2}-4^{\text {th }}$ week of June & 87.5 & 2.6 & 7.3 & 6.5 \\
\hline$D_{3}-2^{\text {nd }}$ Week of July & 88.7 & 2.5 & 7.1 & 6.4 \\
\hline$D_{4}-4^{\text {th }}$ Week of July & 77.8 & 2.1 & 6.4 & 6.1 \\
\hline S.E. \pm & 2.08 & 0.04 & 0.11 & 0.13 \\
\hline C.D. 0.05 & 7.21 & 0.14 & 0.39 & 0.45 \\
\hline \multicolumn{5}{|l|}{ B. Varieties (4) } \\
\hline$V_{1}-$ Phule Nachani & 94.3 & 2.7 & 8.2 & 6.8 \\
\hline$V_{2}-$ GPU 28 & 87.0 & 2.6 & 7.1 & 6.3 \\
\hline$V_{3}-\mathbf{G P U} 67$ & 82.5 & 2.4 & 6.7 & 6.4 \\
\hline $\mathbf{V}_{4}-$ Dapoli 1 & 75.3 & 2.1 & 5.7 & 5.3 \\
\hline S.E. \pm & 0.90 & 0.05 & 0.21 & 0.11 \\
\hline C.D. 0.05 & 2.61 & 0.15 & 0.60 & 0.32 \\
\hline \multicolumn{5}{|l|}{ Interaction } \\
\hline S.E. \pm & 1.79 & 0.10 & 0.41 & 0.22 \\
\hline C.D. 0.05 & NS & NS & NS & NS \\
\hline
\end{tabular}


Table.2 Pooled mean grain and straw yield $\left(\mathrm{q} \mathrm{ha}{ }^{-1}\right)$ of finger millet as influenced by different treatments

\begin{tabular}{|c|c|c|c|c|c|c|c|c|}
\hline \multirow{2}{*}{$\begin{array}{c}\text { Treatments } \\
\text { A. Sowing dates (4) }\end{array}$} & \multicolumn{3}{|c|}{ Grain Yield $\left(q\right.$ ha $\left.^{-1}\right)$} & \multirow[t]{2}{*}{ Mean } & \multicolumn{3}{|c|}{ Grain Yield $\left(q\right.$ ha $\left.^{-1}\right)$} & \multirow[t]{2}{*}{ Mean } \\
\hline & 2016 & 2017 & 2018 & & 2016 & 2017 & 2018 & \\
\hline$D_{1}-2^{\text {nd }}$ Week of June & 13.19 & 16.32 & 12.52 & 14.21 & 17.23 & 19.09 & 15.91 & 17.41 \\
\hline$D_{2}-4^{\text {th }}$ week of June & 18.91 & 20.14 & 15.57 & 18.20 & 24.58 & 26.43 & 19.88 & 23.64 \\
\hline$D_{3}-2^{\text {nd }}$ Week of July & 17.79 & 18.40 & 14.26 & 16.82 & 23.12 & 26.08 & 18.29 & 22.50 \\
\hline$D_{4}-4^{\text {th }}$ Week of July & 11.77 & 12.64 & 9.71 & 11.37 & 13.94 & 15.94 & 12.32 & 14.07 \\
\hline S.E. \pm & 0.34 & 0.82 & 0.57 & 0.36 & 0.57 & 0.88 & 0.74 & 0.71 \\
\hline C.D. 0.05 & 1.19 & 2.84 & 1.98 & 1.25 & 1.97 & 3.51 & 2.56 & 2.45 \\
\hline \multicolumn{9}{|l|}{ B. Varieties (4) } \\
\hline$V_{1}-$ Phule Nachani & 17.71 & 20.40 & 16.76 & 18.30 & 22.66 & 26.37 & 22.14 & 23.74 \\
\hline$V_{2}-$ GPU 28 & 17.11 & 18.34 & 13.75 & 16.40 & 21.11 & 24.35 & 17.57 & 21.00 \\
\hline$V_{3}-$ GPU 67 & 15.08 & 15.70 & 11.77 & 14.18 & 19.31 & 20.42 & 14.65 & 18.12 \\
\hline$V_{4}-$ Dapoli 1 & 12.34 & 13.02 & 9.77 & 11.71 & 15.80 & 16.41 & 12.05 & 14.75 \\
\hline S.E. \pm & 0.54 & 0.71 & 0.49 & 0.23 & 0.86 & 1.04 & 0.60 & 0.43 \\
\hline C.D. 0.05 & 1.57 & 2.07 & 1.42 & 0.68 & 2.52 & 3.04 & 1.76 & 1.26 \\
\hline \multicolumn{9}{|l|}{ Interaction } \\
\hline S.E. \pm & 1.07 & 1.42 & 1.02 & 0.47 & 1.73 & 2.08 & 1.28 & 0.86 \\
\hline C.D. 0.05 & NS & NS & NS & 1.36 & NS & NS & NS & 2.51 \\
\hline
\end{tabular}

Table.3 Pooled mean grain and straw yield $\left(\mathrm{q} \mathrm{ha}^{-1}\right)$ of finger millet as influenced by different treatments - Sowing dates X Varieties

\begin{tabular}{|c|c|c|c|c|c|}
\hline \multirow{2}{*}{ Treatments } & \multicolumn{4}{|c|}{ Grain yield $\left(\mathbf{q ~ h a}^{-1}\right)$} & \multirow[t]{2}{*}{ Mear } \\
\hline & $\begin{array}{l}V_{1} \text { - Phule } \\
\text { Nachani }\end{array}$ & $\mathrm{V}_{2^{-}}$GPU 28 & $\mathrm{~V}_{3^{-}}$GPU 67 & $\mathrm{~V}_{4^{-}}$Dapoli 1 & \\
\hline$D_{1}-2^{\text {nd }}$ week of June & 17.32 & 14.82 & 13.83 & 10.85 & 14.21 \\
\hline$D_{2}-4^{\text {th }}$ week of June & 22.51 & 19.98 & 17.06 & 13.26 & 18.20 \\
\hline$D_{3}-2^{\text {nd }}$ week of July & 19.84 & 17.66 & 16.30 & 13.47 & 16.82 \\
\hline$D_{4}-4^{\text {th }}$ week of July & 13.55 & 13.13 & 9.53 & 9.27 & 11.37 \\
\hline \multirow[t]{2}{*}{ Mean } & 18.30 & 16.40 & 14.18 & 11.71 & 15.15 \\
\hline & $\begin{array}{l}\text { Sowing } \\
\text { date }\end{array}$ & Varieties & $\begin{array}{c}\text { Interrelation } \\
\text { Dates X Varieties }\end{array}$ & & \\
\hline S.E. \pm & 0.36 & 0.23 & 0.47 & & \\
\hline C.D. 0.05 & 1.25 & 0.68 & 1.36 & & \\
\hline
\end{tabular}

\begin{tabular}{|c|c|c|c|c|c|}
\hline \multirow[t]{2}{*}{ Treatments } & \multicolumn{4}{|c|}{ Straw yield $\left(q\right.$ ha $\left.^{-1}\right)$} & \multirow[t]{2}{*}{ Mean } \\
\hline & $\begin{array}{l}\mathrm{V}_{1} \text { - Phule } \\
\text { Nachani }\end{array}$ & $\mathrm{V}_{2}$ - GPU 28 & $\mathrm{~V}_{3^{-}}$GPU 67 & $\mathrm{~V}_{4^{-}}$Dapoli 1 & \\
\hline$D_{1}-2^{\text {nd }}$ week of June & 21.89 & 19.21 & 16.20 & 12.32 & 17.41 \\
\hline$D_{2}-4^{\text {th }}$ week of June & 29.88 & 25.69 & 21.93 & 17.04 & 23.64 \\
\hline$D_{3}-2^{\text {nd }}$ week of July & 25.77 & 23.69 & 22.43 & 18.09 & 22.50 \\
\hline $\mathrm{D}_{4}-4^{\text {th }}$ week of July & 17.40 & 15.41 & 11.93 & 11.55 & 14.07 \\
\hline \multirow[t]{2}{*}{ Mean } & 23.74 & 21.00 & 18.12 & 14.75 & 19.40 \\
\hline & $\begin{array}{l}\text { Sowing } \\
\text { date }\end{array}$ & Varieties & $\begin{array}{c}\text { Interrelation } \\
\text { Dates X Varieties }\end{array}$ & & \\
\hline S.E. \pm & 0.71 & 0.43 & 0.86 & & \\
\hline C.D. 0.05 & 2.45 & 1.26 & 2.51 & & \\
\hline
\end{tabular}


Table.4 Pooled economics of finger millet as influenced by different treatments (Economics Interaction) - Sowing dates $\mathrm{X}$ Varieties

\begin{tabular}{|c|c|c|c|c|c|}
\hline \multirow[t]{2}{*}{ Treatments } & \multicolumn{4}{|c|}{ Gross Monetary Returns (Rs. ha $\left.{ }^{-1}\right)$} & \multirow[t]{2}{*}{ Mean } \\
\hline & $\begin{array}{l}\mathrm{V}_{1} \text { - Phule } \\
\text { Nachani }\end{array}$ & $\mathrm{V}_{2}$ - GPU 28 & $\mathrm{~V}_{3^{-}}$GPU 67 & $\mathrm{~V}_{4}$ - Dapoli 1 & \\
\hline$D_{1}-2^{\text {nd }}$ week of June & 42498 & 37130 & 34468 & 27073 & 35292 \\
\hline$D_{2}-4^{\text {th }}$ week of June & 56689 & 49922 & 42375 & 32937 & 45481 \\
\hline$D_{3}-2^{\text {nd }}$ week of July & 49979 & 43975 & 40661 & 33546 & 42040 \\
\hline $\mathrm{D}_{4}-4^{\text {th }}$ week of July & 34250 & 32563 & 23642 & 22970 & 28356 \\
\hline Mean & 45853 & 40897 & 35286 & 29131 & 37792 \\
\hline & Sowing date & Varieties & Dates $\mathrm{X}$ varieties & & \\
\hline S.E. \pm & 594 & 807 & 1613 & & \\
\hline C.D. 0.05 & 2055 & 2354 & 4709 & & \\
\hline
\end{tabular}

\begin{tabular}{|c|c|c|c|c|c|}
\hline \multirow[t]{2}{*}{ Treatments } & \multicolumn{4}{|c|}{ Net Monetary Returns (Rs. ha ${ }^{-1}$ ) } & \multirow[t]{2}{*}{ Mean } \\
\hline & $\begin{array}{l}\mathrm{V}_{1} \text { - Phule } \\
\text { Nachani }\end{array}$ & $\mathrm{V}_{2^{-}}$GPU 28 & $\mathrm{~V}_{3^{-}}$GPU 67 & $\mathrm{~V}_{4^{-}}$Dapoli 1 & \\
\hline$D_{1-} 2^{\text {nd }}$ week of June & 13413 & 6775 & 4113 & -3282 & 5188 \\
\hline$D_{2}-4^{\text {th }}$ week of June & 26334 & 19567 & 12020 & 2583 & 15126 \\
\hline$D_{3}-2^{\text {nd }}$ week of July & 19625 & 13620 & 10306 & 3191 & 11686 \\
\hline$D_{4}-4^{\text {th }}$ week of July & 3895 & 2208 & -6712 & -7385 & -1998 \\
\hline Mean & 15749 & 10542 & 4931 & -1223 & 7500 \\
\hline & Sowing date & Varieties & $\begin{array}{l}\text { Dates X } \\
\text { Varieties }\end{array}$ & & \\
\hline S.E. \pm & 632 & 788 & 1577 & & \\
\hline C.D. 0.05 & 2189 & 2301 & 4602 & & \\
\hline
\end{tabular}

\begin{tabular}{|c|c|c|c|c|c|}
\hline \multirow[t]{2}{*}{ Treatments } & \multicolumn{4}{|c|}{ B : C Ratio) } & \multirow[t]{2}{*}{ Mean } \\
\hline & $\begin{array}{l}V_{1} \text { - Phule } \\
\text { Nachani }\end{array}$ & $\mathrm{V}_{2}$ - GPU 28 & $\mathrm{~V}_{3^{-}}$GPU 67 & $\mathrm{~V}_{4}$ - Dapoli 1 & \\
\hline$D_{1}-2^{\text {nd }}$ week of June & 1.43 & 1.22 & 1.13 & 0.89 & 1.17 \\
\hline$D_{2}-4^{\text {th }}$ week of June & 1.86 & 1.64 & 1.40 & 1.09 & 1.50 \\
\hline$D_{3}-2^{\text {nd }}$ week of July & 1.64 & 1.45 & 1.34 & 1.11 & 1.39 \\
\hline$D_{4}-4^{\text {th }}$ week of July & 1.12 & 1.07 & 0.78 & 0.76 & 0.93 \\
\hline \multirow[t]{2}{*}{ Mean } & 1.51 & 1.35 & 1.16 & 0.96 & \\
\hline & Sowing date & Varieties & $\begin{array}{l}\text { Dates X } \\
\text { Varieties }\end{array}$ & & \\
\hline S.E. \pm & 0.02 & 0.02 & 0.05 & & \\
\hline C.D. 0.05 & 0.07 & 0.07 & 0.13 & & \\
\hline
\end{tabular}


The interaction effects between sowing dates and varieties were found to significant. The finger millet variety Phule Nachani sown during $4^{\text {th }}$ week of June recorded significantly highest gross and net monetary returns as well as B: C ratio (Rs. 56689, Rs. 26334, 1.86 respectively). The lowest gross returns, net returns and $\mathrm{B}: \mathrm{C}$ ratio were noticed with Dapoli 1 variety sown during $30^{\text {th }} \mathrm{MW}$ i.e. in $4^{\text {th }}$ week of July which might be because of lesser grain yield and straw yield. These results are in agreement with the findings of Revathi et al., (2018). From present research it is recommended that sowing of finger millet variety Phule Nachani during $22^{\text {nd }}$ to $28^{\text {th }}$ June $\left(26^{\text {th }} \mathrm{MW}\right)$ for higher grain, straw yield and monetary returns under delayed onset of monsoon in Sub montane Zone of Maharashtra.

\section{Acknowledgments}

We thanks to authorities of All India Coordinated Small Improvement Project, Zonal Agricultural Research Station, Shenda Park, Kolhapur for conduct of research, support and encouragement during experimentation.

\section{References}

Ashok E.G., Reddy V.C. Gowda B.K.L (2012) Effect of sowing dates and spacing on grain yield of finger millet varieties (India). Mysore Journal of Agril. Science, 13(2): 134-136.

Auffhammer, M., Ramanathan, V. and Vincent, J. R. 2012. Climate change, the monsoon, and rice yield in India.
Climatic Change, 111:411-424.

Nagaraju, A. P. and Kumar, H. K. M.2009 Performance of finger millet (Eleusine coracana (L.) Gaertn.) varieties on sowing dates and methods of establishment Mysore Journal of Agricultural Sciences Vol.43 No.2 pp.208-212 ref.3

Pandiselvi T., A.L. Narayanan and R. Karthikeyan 2010 Evaluation of optimum time of sowing of finger millet (Eleusine coracana G.) varieties in Karaikal region I Internat. J.agric. Sci., 6(1): 94-96.

Panse V. G. and Sukhatme P. V. 1985. Statistical methods for agricultural workers. ICAR, New Delhi, pp. 145148.

Parasuraman P. 2001. Response of farming studies in respect of finger millet (Eleusine coracanna L) under erratic monsoon condition of North-Western agroclimatic zone of Tamilnadu. Indian Journal of Agronomy Vol. 457 (3) PP 384-389.

Revathi T., M. Sree Rekha and S. Pradeepkumar 2018 Ensuing Economic Gains from Finger millet (Eleusine coracana L.) due to Different Dates of Sowing and Varieties Int. J. Curr. Microbiol. App. Sci (2018) Special Issue-6: 2050-2054.

Seetharam A (2006) Millets: Handbook of Agriculture. Directorate of Information and Publications of Agriculture Indian Council of Agricultural Research, Krishi Anusandhan Bhavan, Pusa, New Delhi-110012. India. Pp. 892-912.

\section{How to cite this article:}

Nigade, R. D., S. V. Bagade and Bhilare, R. L. 2020. Ensuing Economic Gains due to Different Dates of Sowing on Finger millet Varieties (Eleusine coracana L.). Int.J.Curr.Microbiol.App.Sci. 9(05): 2487-2492. doi: https://doi.org/10.20546/ijcmas.2020.905.284 